\title{
RACK1 promotes lung cancer cell growth via an MCM7/RACK1/ Akt signaling complex
}

\author{
Liangru Fei ${ }^{1}$, Yinan Ma ${ }^{1}$, Meiyu Zhang ${ }^{1}$, Xiaofang Liu ${ }^{2}$, Yuan Luo ${ }^{1}$, Congcong Wang ${ }^{2}$, \\ Haiyan Zhang ${ }^{3}$, Wenzhu Zhang ${ }^{1}$ and Yuchen Han ${ }^{1,2}$ \\ ${ }^{1}$ Department of Pathology, School of Basic Medical Sciences, China Medical University, Shenyang 110000, China \\ ${ }^{2}$ Department of Pathology, The First Affiliated Hospital of China Medical University, Shenyang 110000, China \\ ${ }^{3}$ Department of Pathology, The First People's Hospital of Jining, Shandong 272000, China
}

Correspondence to: Yuchen Han, email: ychan@cmu.edu.cn

Keywords: RACK1, MCM7, proliferation, NSCLC, Akt

Received: December 16, $2016 \quad$ Accepted: April 03, $2017 \quad$ Published: April 15, 2017

Copyright: Fei et al. This is an open-access article distributed under the terms of the Creative Commons Attribution License 3.0 (CC BY 3.0 ), which permits unrestricted use, distribution, and reproduction in any medium, provided the original author and source are credited.

\begin{abstract}
MCM7, a member of the miniature chromosome maintenance (MCM) protein family, is crucial for the initiation of DNA replication and proliferation in eukaryotic cells. In this report, we demonstrate that RACK1 regulates cell growth and cell cycle progression in human non-small-cell lung cancer by mediating MCM7 phosphorylation through an MCM7/RACK1/Akt signaling complex. RACK1 functions as a central scaffold that brings Akt into physical proximity with MCM7. Overexpression of RACK1 increases interactions between Akt and MCM7 and promotes Akt-dependent MCM7 phosphorylation, which in turn increases MCM7 binding to chromatin and MCM complex formation. Together, these changes promote DNA replication and cell proliferation. Our findings reveal a novel signaling pathway that regulates growth in non-small cell lung cancer.
\end{abstract}

\section{INTRODUCTION}

A heterohexameric complex composed of MCM2-7, which acts as a DNA replication ligase with helicase activity at replication forks, initiates chromosomal duplication, a highly precise event that maintains genome stability [1-6]. MCM proteins $2-7$, which are highly conserved between yeast and humans, are recruited to chromatin and bind with origin recognition complex (ORC), Cdt1, and cdc6 to form the pre-replication complex (Pre-RC) early during the G1 phase, ultimately initiating DNA replication $[7,8]$. Moreover, numerous studies have demonstrated that MCM7 is a pivotal component of the DNA replication initiation complex in Xenopus and yeast [9-12]; it also serves as a proliferation marker and is correlated with tumorigenesis in several human malignancies, including prostate cancer [13], ovarian cancer [14], endometrial carcinoma [15], oral squamous cell carcinoma [16], esophageal adenocarcinoma [17], colorectal adenocarcinoma [18], and glioblastoma [19]. In addition, MCM7 is associated with mRNA transcription and DNA damage [20-22]. Recent studies have demonstrated that MCM7 is a potential therapeutic target in several cancers [13, 23-25].
Receptor for activated C kinase 1 (RACK1) is a highly-conserved WD40 repeat scaffold protein that belongs to the Trp-Asp (WD) repeat protein family. Individual WD40 repeats can simultaneously interact with multiple signaling molecules, including PKC [26], Src [27-29], integrin [30], EphB3 [31], and c-Abl [32], which allows RACK1 to integrate inputs from various signaling pathways [33]. RACK1 therefore plays a pivotal role in many critical cellular processes. Activation of Akt, a Ser/ Thr kinase that participates in many cellular processes by facilitating growth factor-mediated cell survival and blocking apoptosis [34], is associated with tumorigenesis in various human cancers. In addition, a recent study in NSCLC revealed that P-Thr308, but not P-Ser473, which is widely used as a marker of Akt activity, is the major regulator of Akt protein kinase activity [35].

Here, we found that RACK1 was up-regulated in NSCLC, and knockdown of RACK1 inhibited cellular growth and blocked S phase entry. Furthermore, we demonstrated that the oncogenic potential of RACK1 was correlated with MCM7 function. RACK1 regulated the recruitment of MCM7 to chromatin and its interaction with other MCM proteins by regulating its phosphorylation via 
an MCM7/RACK1/Akt signaling complex. These results suggest that RACK1 promotes growth in NSCLC by facilitating interactions between MCM7 and Akt.

\section{RESULTS}

\section{RACK1 promotes cellular proliferation by regulating G1/S progression in NSCLC cells}

To understand the function of RACK1 in NSCLC cells, we used siRACK1 to knock down its expression in the A549 and H460 NSCLC cell lines. RACK1 knockdown inhibited, while RACK1 overexpression promoted, cell growth and colony formation (Figure 1A and 1B). Furthermore, flow cytometry revealed that RACK1 knockdown effectively blocked entry into S-phase and reduced the percentage of cells in S-phase, suggesting that RACK1 might regulate the G1 checkpoint (Figure 1C). To confirm this, we examined the effects of RACK1 on regulators of cell cycle progression at the G1/S boundary. Downregulation of RACK1 decreased cyclinD1 levels, induction of the CDK inhibitor p27, dephosphorylation of $\mathrm{Rb}$, and sequestration of the transcription factor E2F1, but did not alter CDK2, CDK4, or Rb expression, in G1 cells compared to negative controls (Figure 1D).

\section{RACK1 interacts with MCM7}

RACK1 is a scaffold protein that is able to interact with several signaling molecules simultaneously [36]. A two-hybrid yeast assay revealed that RACK1 bound with MCM7, which was a potential downstream regulator of G1/S transition in NSCLC (Figure 2A). Double immunofluorescence staining in A549 and H460 cells indicated that RACK1 was mainly localized in the cytoplasm but was also expressed to a lesser degree in the nucleus together with MCM7 (Figure 2B). Both endogenous (Figure 2C) and exogenous (Figure 2D) coimmunoprecipitation of RACK1 and MCM7 confirmed their interaction.

\section{RACK1 and MCM7 expression are elevated in clinical NSCLC samples}

Next, we performed immunohistochemical staining for the RACK1/MCM7 complex in NSCLC specimens. RACK1 and MCM7 expression were higher in in situ carcinoma and cancer cells than in normal bronchial epithelium cells (Figure 3A). We then performed immunohistochemical analysis of 150 NSCLC samples using tissue chips and found that RACK1 levels were positively correlated with MCM7 levels (Table 1). Moreover, both RACK1 and MCM7 levels were positively correlated with histological grade, lymphatic metastasis, and tumor TNM stage (Table 2). A log-rank test showed that NSCLC patients with high RACK1 and MCM7 levels had shorter overall survival (Figure 3B). To further confirm these findings, we assessed RACK1 and MCM7 mRNA and protein levels in an additional 28 pairs of matched NSCLC and normal lung tissue samples. mRNA and protein levels of both RACK1 and MCM7 were higher in tumor tissue than in the normal lung counterparts (Figure 3C and 3D). Taken together, these findings indicate that RACK1 and MCM7 are important promoters of NSCLC development and progression.

\section{RACK1 promotes phosphorylation of MCM7}

We then examined the mechanism by which RACK1 interacts with MCM7. Interestingly, RACK1 promoted the phosphorylation of MCM7 (Figure 4A), which increases its activity [37-39]. As expected, phosphorylation of MCM7 increased its recruitment to chromatin and MCM complex formation (Figure 4B and 4C), which are both critical for DNA replication and cellular proliferation $[40,41]$. These results suggest that RACK1 promotes cellular growth and cell cycle progression via phosphorylation of MCM7.

\section{RACK1 promotes MCM7 phosphorylation indirectly via the Akt signaling pathway}

Because RACK1 is a scaffold protein that does not contain catalytic domains, it likely promotes phosphorylation of MCM7 indirectly. Akt also interacted with RACK1 and MCM7; both endogenous (Figure 5A) and exogenous (Figure 5B) co-immunoprecipitation experiments confirmed the existence of a ternary MCM7/ RACK1/Akt complex. Furthermore, Akt levels were positively correlated with MCM7 phosphorylation levels (Figure 5C-5E) and chromatin binding (Figure 6A-6C). These results suggest that RACK1 indirectly promotes MCM7 activation via the Akt signaling pathway. We therefore investigated whether Akt pathway-induced MCM7 serine/threonine phosphorylation was dependent on RACK1. RACK1 knockdown abolished Akt pathwayinduced MCM7 phosphorylation (Figure 7A). RACK1 therefore plays an essential role by indirectly promoting MCM7 phosphorylation through the Akt signaling pathway.

\section{DISCUSSION}

Here, we demonstrated that RACK1 regulates growth and cell cycle progression in human NSCLC by promoting MCM7 phosphorylation as a component of an MCM7/RACK1/Akt signaling complex. These findings describe a novel mechanism by which promotes proliferation in NSCLC.

Due to its ability to regulate reversible phosphorylation via interactions with protein kinases, phosphatases, and their substrates, RACK1 has been recognized as an important 
component of signal transduction in several pathways [42]. Overexpression of RACK1 served as a biomarker associated with increased pathological stage, tumor size, and lymph node involvement in pulmonary adenocarcinoma in a recent study [43]. In addition, RACK1 promotes NSCLC by interacting with and activating Smoothened, which in turn mediates Gli1-dependent transcription in NSCLC cells [44]. In this study, we identified a novel signaling pathway by which RACK1 together with MCM7 regulates cell growth and cell cycle progression in NSCLC. MCM7 has long
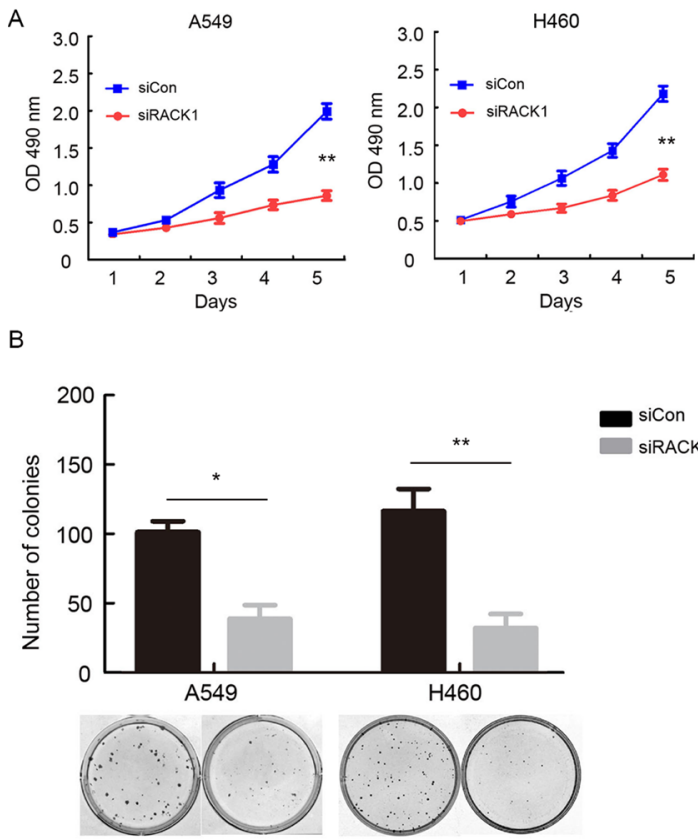

C
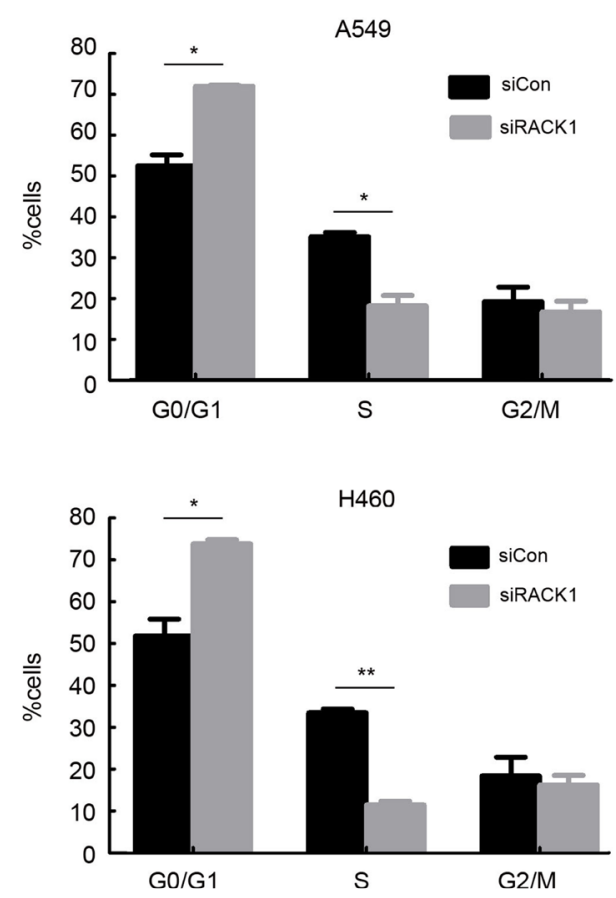

D
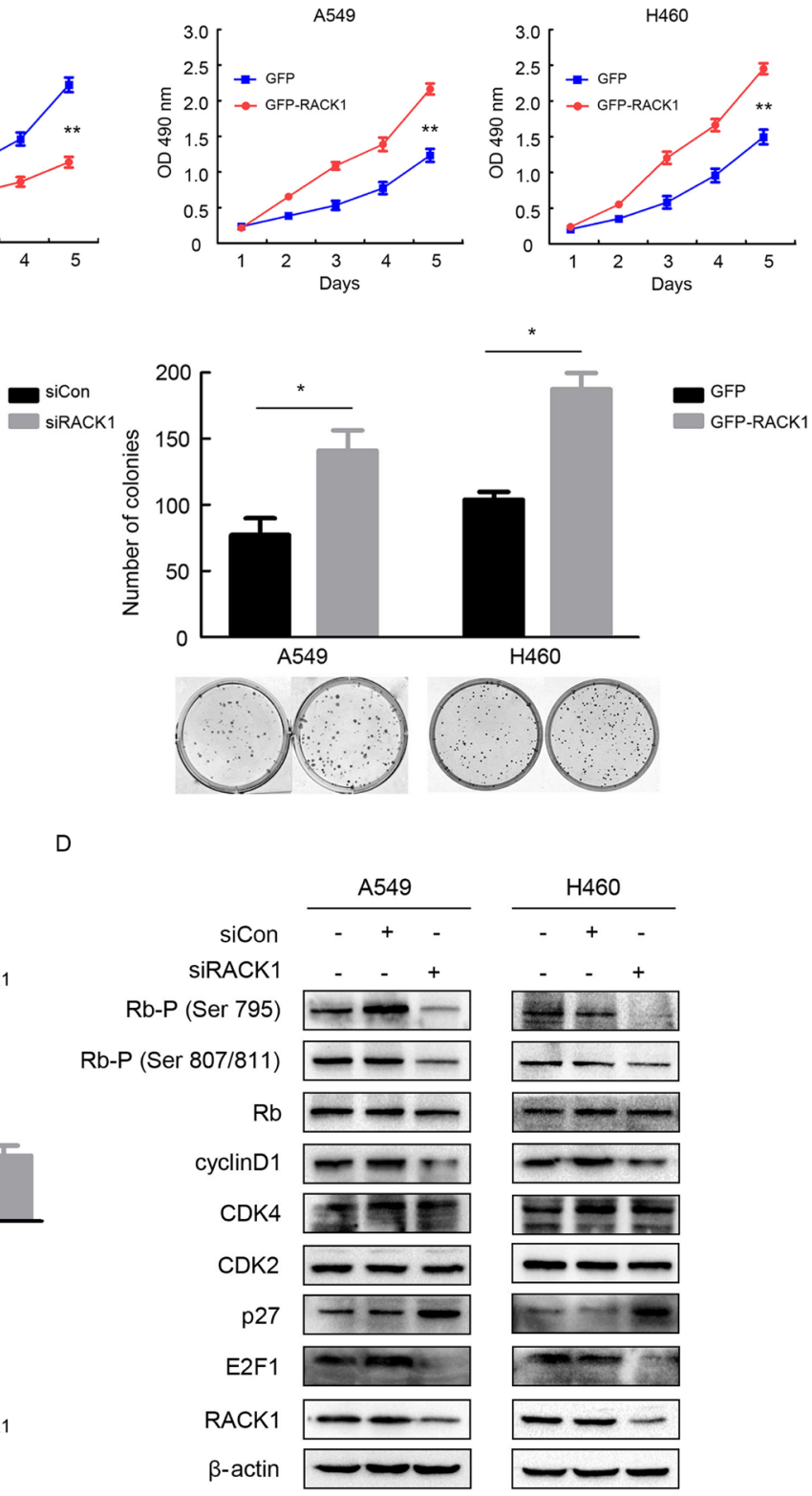

Figure 1: RACK1 promotes cellular proliferation by regulating G1/S progression in NSCLC cells. A549 and H460 cell lines were transfected with siRNA RACK1 (siRACK1), siRNA control (siCon), pEGFP-N1-RACK1 (GFP-RACK1), or pEGFP-N1 (GFP) as indicated. (A) MTT assays for A549 and H460 siRACK1, siCon, GFP-RACK1, and GFP cells. (B) A549 and H460 cells were plated in 40-mm dishes $24 \mathrm{~h}$ after transfection and cultured in media supplemented with $10 \%$ FBS for 12 days, after which the number of colonies with more than 50 cells was counted. (C and D) A549 and H460 cells were synchronized at the G0/G1 phase by serum starvation, cell cycle progression was then triggered by the addition of $10 \%$ FBS for $4 \mathrm{~h}$, and flow cytometry (C) and the activity of G1 cell cycle regulators (D) were analyzed to evaluate cell cycle progression. 
Table 1: Correlation between RACK1 and MCM7 expression in NSCLC

MCM7 expression

\begin{tabular}{|c|c|c|c|c|c|c|}
\hline & & Positiv & & Negative & & \\
\hline & & & $N$ & & $\mathrm{R}$ & $P$ value \\
\hline \multirow{2}{*}{ RACK1 expression } & Positive & 89 & & 19 & \multirow{2}{*}{0.555} & \multirow{2}{*}{$<0.001$} \\
\hline & Negative & 10 & & 32 & & \\
\hline
\end{tabular}

Table 2: Relationship between RACK1 and MCM7 expression and clinical and pathological features in NSCLC patients

\begin{tabular}{|c|c|c|c|c|c|}
\hline Clinical characteristics & No. patients & MCM7-positive & $P$ value & RACK1-positive & $P$ value \\
\hline \multicolumn{6}{|l|}{ Age } \\
\hline$<55$ & 22 & 14 & \multirow{2}{*}{0.811} & 15 & \multirow{2}{*}{0.797} \\
\hline$\geq 55$ & 128 & 85 & & 93 & \\
\hline \multicolumn{6}{|l|}{ Gender } \\
\hline Male & 118 & 81 & \multirow{2}{*}{0.130} & 84 & \multirow{2}{*}{0.664} \\
\hline Female & 32 & 14 & & 21 & \\
\hline \multicolumn{6}{|l|}{ Histological grade } \\
\hline I-II & 89 & 39 & \multirow{2}{*}{0.012} & 44 & \multirow{2}{*}{0.020} \\
\hline III & 61 & 40 & & 46 & \\
\hline \multicolumn{6}{|l|}{ Lymphatic metastasis } \\
\hline Negative & 98 & 43 & \multirow{2}{*}{0.026} & 48 & \multirow{2}{*}{0.024} \\
\hline Positive & 52 & 33 & & 36 & \\
\hline \multicolumn{6}{|l|}{ TNM classification } \\
\hline I-II & 102 & 58 & \multirow{2}{*}{0.019} & 55 & \multirow{2}{*}{0.032} \\
\hline III-IV & 48 & 37 & & 35 & \\
\hline
\end{tabular}

been considered a vital component in the initiation of DNA replication. Numerous studies suggest that phosphorylation of MCM7 is directly correlated with its binding to chromatin and other MCM family members, and decreases in this binding inhibit the helicase activity of MCM7, DNA replication, S-phase entry, and cancer cell growth [38-40]. In addition, binding of TPA to PKC activates PKC and its binding to RACK1, which in turn triggers translocation of RACK1 from the nucleus to the cytoplasm, inactivation of MCM7, and disintegration of the DNA replication initiation complex in prostate cancer [41]. However, the specific mechanism by which RACK1 regulates MCM7 activity remains unclear. Here, we found that RACK1 functioned as a central scaffold that brought Akt and MCM7 into close physical proximity in NSCLC cells. Knockdown of RACK1 inhibited the interaction between Akt and MCM7 and decreased Akt-induced phosphorylation of MCM7, resulting in dissociation of MCM7 from chromatin and destruction of the MCM complex. Moreover, RACK1 knockdown inhibited DNA replication and S-phase entry by increasing cell cycle arrest at the G1/S transition checkpoint. In contrast, RACK1 overexpression had the opposite effects. It has also been reported that RACK1 promotes growth in other cancers by affecting key cell cycle regulators. $\mathrm{Li}$ et al. reported that downregulation of RACK1 decreased Cyclin D1 expression and induced G1/S cell cycle arrest in pancreatic ductal adenocarcinoma [45]. Lv et al. found that knockdown of RACK1 suppressed Cyclin D1 and CDK6 expression, thereby dramatically increasing G0/G1 phase and reducing S phase cell populations, in glioma [46]. Zhang et al. reported that stable RACK1 knockdown downregulated Cyclin B1 and Cyclin D1 and promoted G1 and G2 phase arrest in oral squamous cell carcinoma [47]. Interestingly, RACK1 has the opposite effect in colon cancer cells; RACK1 overexpression delays passage of HT-29 cells through G1 and mitotic checkpoints by suppressing Src-mediated Sam68 phosphorylation and maintaining the active state of CDK1-cyclinB $[48,49]$. 
In contrast to previous studies, we found here that, although RACK1 was mainly localized in the cytoplasm, it was also expressed to a lesser degree in the nucleus. It has been reported that $\mathrm{CAMP} / \mathrm{PKA}$ pathway activation may promote the translocation of RACK1 from the cytoplasm to the nucleus [50-53]. In addition, previous studies have obtained contradictory results regarding the role of RACK 1 in regulating Akt activity in different cell types $[31,42,54-56]$. Our results indicate that RACK1 functions as a protein scaffold that forms a complex by dynamically recruiting MCM7 and Akt. However, there may be other mechanisms by which RACK1 regulates the Akt signaling pathway. In addition, we found that MCM7 phosphorylation was positively correlated with Akt signaling pathway activity in the presence of RACK1, as the MCM7 phosphorylation level was consistent with Akt activity resulting from enhanced IGF-1 stimulation. However, because MCM7 was not confirmed as a direct substrate of Akt, the specific phosphorylation sites and mechanism remain unclear. It is possible that MCM7 phosphorylation is regulated by another protein that also interacts with the Akt signaling pathway. Regardless, immunohistochemical analysis demonstrated that RACK1 expression was positively correlated with MCM7 expression and promoted tumorigenesis in NSCLC.
In conclusion, our results suggest that the scaffold protein RACK1 promotes progression in NSCLC progression by indirectly activating MCM7.

\section{MATERIALS AND METHODS}

\section{Cell culture and synchronization}

Human A549 lung adenocarcinoma cells and H460 large cell lung cancer cells (cell resource center of Shanghai Institutes for Biological Sciences, Chinese Academy of Sciences) were cultured in RPMI 1640 medium supplemented with $10 \%$ fetal bovine serum (FBS). For synchronization, cells were starved in medium without serum for $48 \mathrm{~h}$.

\section{Antibodies and reagents}

Antibodies for Akt, Akt-Ser(P)-473, AktThr(P)-308, Rb, Rb-Ser(P)-807/811, Rb-Ser(P)-795, Cdk2, Cdk4, CyclinD1, GFP, Thr(P), perifosine, and human recombinant IGF-1 were from Cell Signaling Technology. Anti-MCM7, Flag, and V5 antibodies were purchased from Santa Cruz. Antibody for RACK1 was from BD Transduction Laboratories. Antibodies for
A

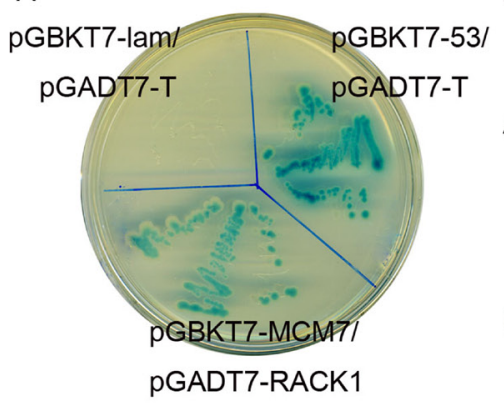

C

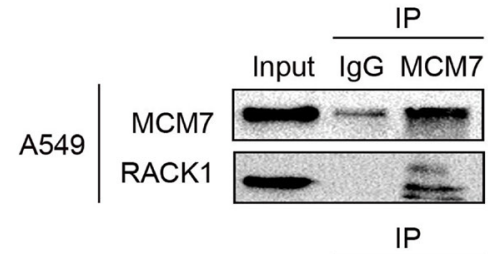

IP

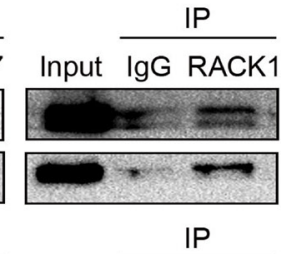

Input IgG MCM7

B

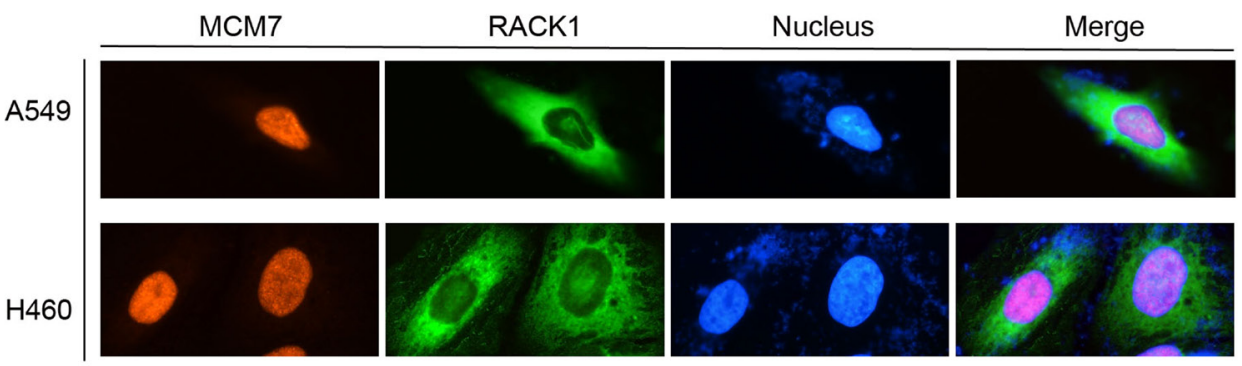

D
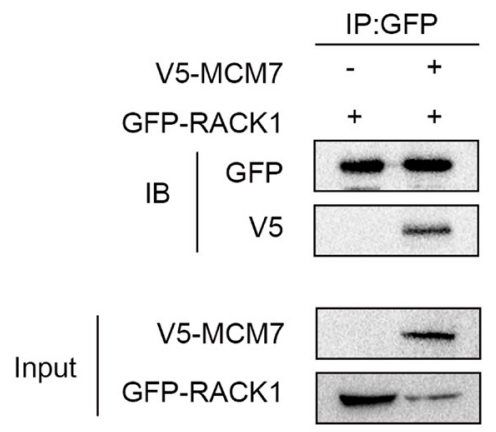

Figure 2: RACK1 interacts with MCM7. (A) pGBKT7-MCM7 and pGADT7-RACK1 co-transformants were grown on SD agar plates with highly stringent nutrient selection (SD-Leu-Trp-His-Ade). pGBKT7-p53 and pGADT7-T-antigen co-transformants were the positive control and pGBKT7-lam and pGADT7-T-antigen co-transformants were the negative control. (B) Immunofluorescence staining of A549 and H460 cells with anti-RACK1 primary and anti-mouse FITC-conjugated secondary antibodies and with anti-MCM7 primary and anti-rabbit TRITC-conjugated secondary antibodies. (C) Co-immunoprecipitation (IP) of RACK1 (left) or MCM7 (right) in A549 and H460 cells. The immunoprecipitates were immunoblotted (IB) with the indicated antibodies. (D) A549 cells were transfected with GFPRACK1 and V5-MCM7, cell lysates were immunoprecipitated with GFP antibody, and immunoblotting was performed with GFP or V5 antibody. 
A

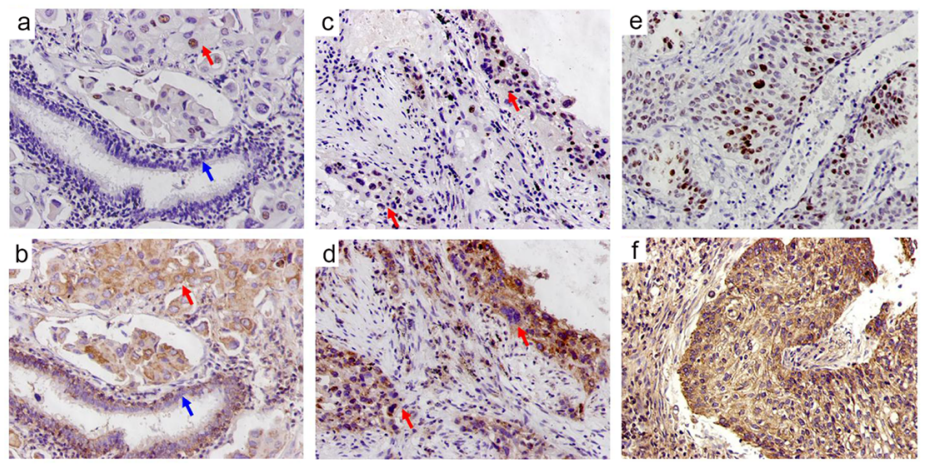

B
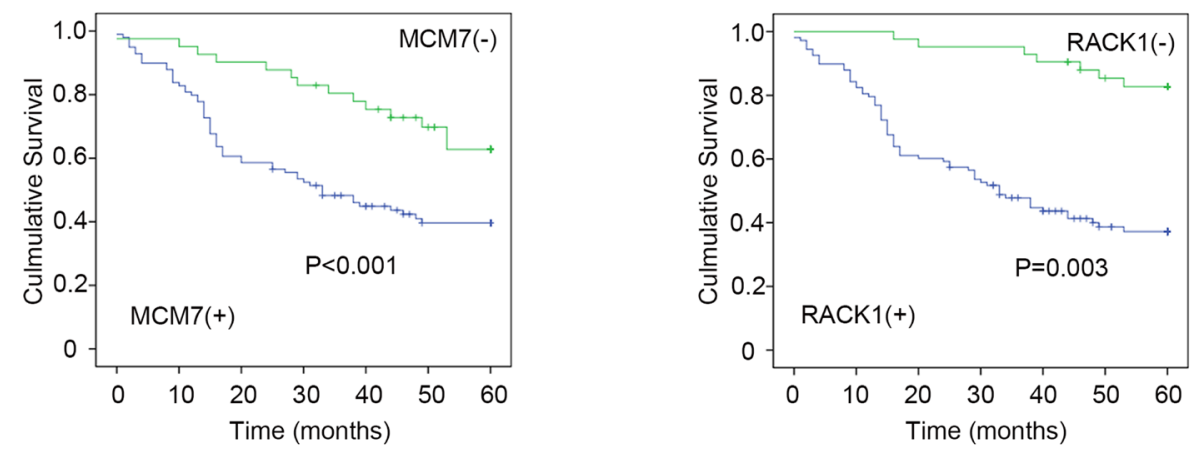

C
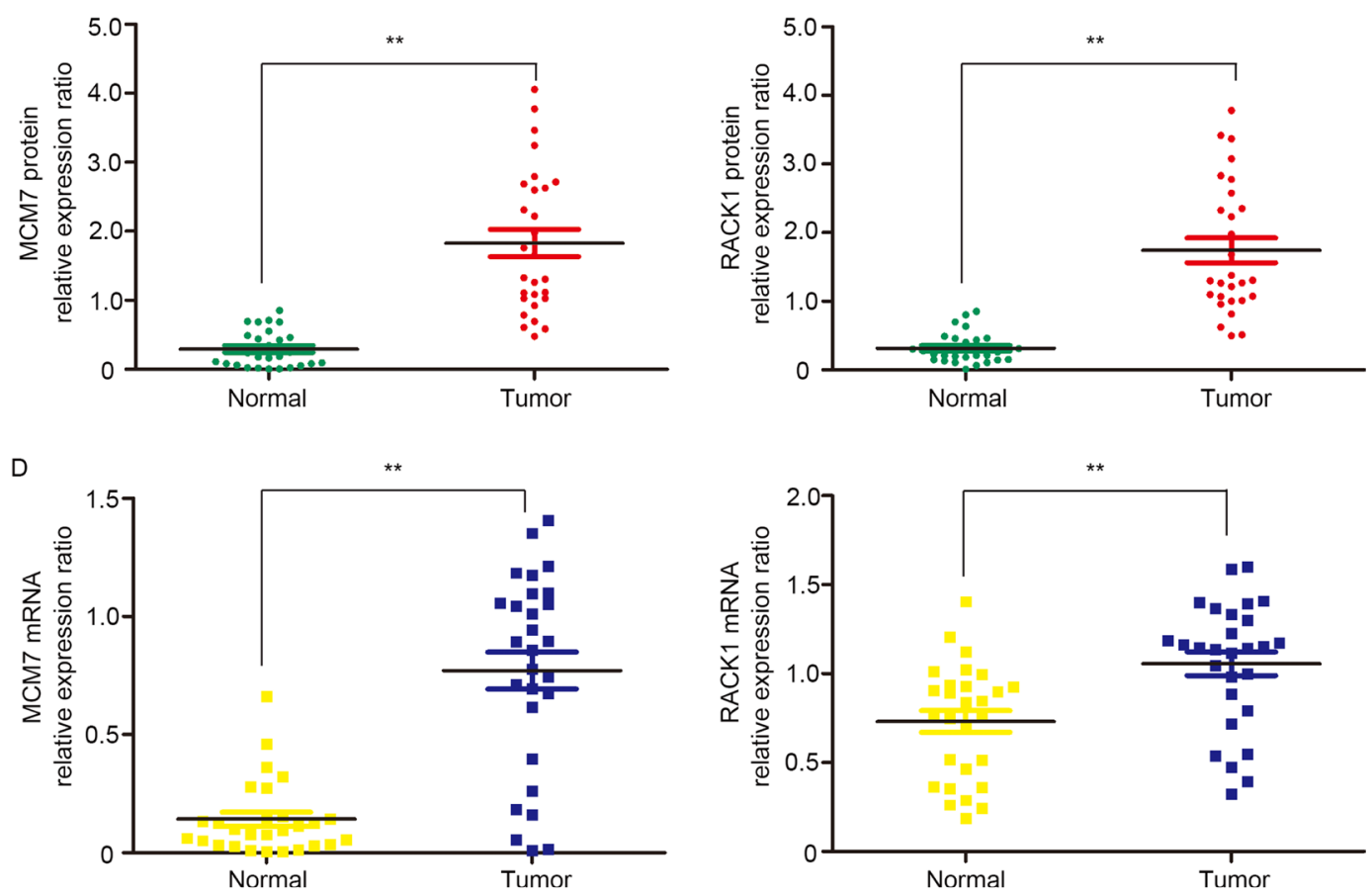

Figure 3: RACK1 and MCM7 expression are elevated in clinical NSCLC samples. (A) Immunohistochemistry was used to examine RACK1 and MCM7 expression in NSCLC. a, Nuclear MCM7 expression in poorly-differentiated adenocarcinoma of the lung (red arrow) and negative expression in normal bronchial epithelium (blue arrow). b, Cytoplasmic RACK1 expression in poorly-differentiated adenocarcinoma of the lung (red arrow) and in normal bronchial epithelium (blue arrow). c, MCM7 expression in in situ carcinoma ( upper red arrow) and in poorly-differentiated squamous cell carcinoma of the lung (lower red arrow). d, RACK1 expression in in situ carcinoma (upper red arrow) and in poorly-differentiated squamous cell carcinoma of the lung (lower red arrow). e, MCM7 expression in poorlydifferentiated squamous cell carcinoma of the lung. f, RACK1 expression in poorly-differentiated squamous cell carcinoma of the lung. (B) Overall survival rates in 150 NSCLC patients were compared between low and high MCM7 (left) and RACK1 (right) level groups using the Kaplan-Meier method. (C) Western blot analysis of MCM7 (left) and RACK1 (right) expression in NSCLC and paired noncancerous tissues. $\beta$-actin protein level was quantified as an internal control. (D) RT-PCR results showing relative expression of MCM7 (left) and RACK1 (right) in NSCLC and paired noncancerous tissues. $\beta$-actin mRNA expression was quantified as an internal control. 
MCM4, MCM6, Cdt1, p27, E2F1, and Histone 3 were from Proteintech Group. Anti-Ser(P) antibody was from Millipore.

\section{Plasmids, siRNAs, and transfection}

Control non-targeting siRNA and siRNAs targeting human RACK1 and Akt were from Santa Cruz. pEGFPN1-RACK1 was a gift from Anna Huttenlocher (Addgene plasmid \# 41088) [57]. pLenti6/V5-DEST-MCM7 was a gift from Lynda Chin (Addgene plasmid \# 31212) [58]. 1477 pcDNA3-Flag-HA-Akt1 was a gift from William

A
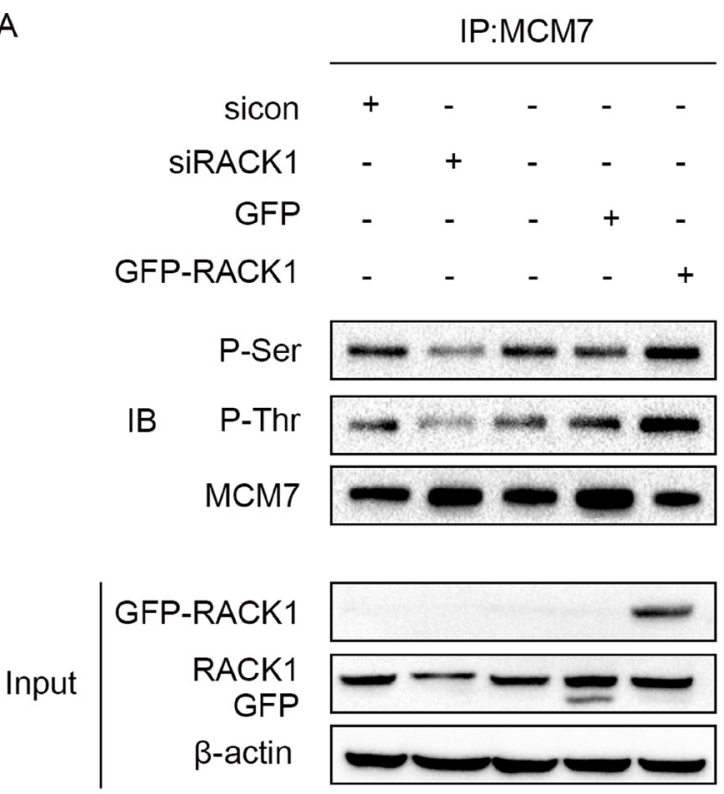

C

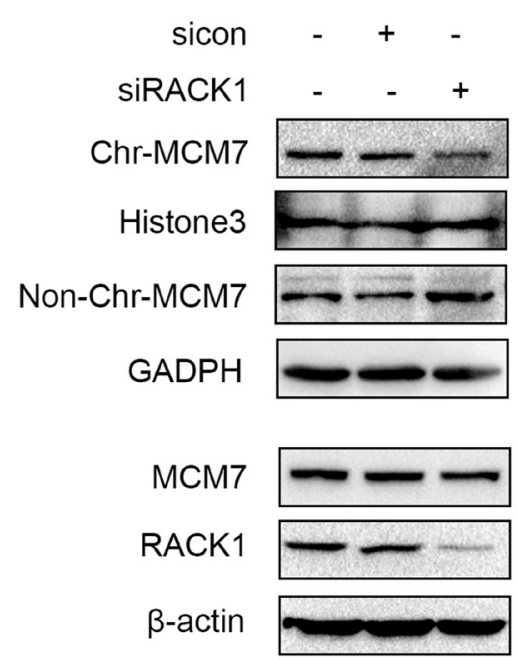

Sellers (Addgene plasmid \# 9021) [59]. pEGFP-N1 was subcloned from pEGFP-N1-RACK1 and pcDNA-Flag-HA was subcloned from pcDNA-Flag-HA-Akt1. pGBKT7MCM7 and pGADT7-RACK1 were kindly provided by Dr. Jianhua Luo, University of Pittsburgh. Cells were transfected using Lipofectamine 3000 (Invitrogen).

\section{Immunoprecipitation and immunoblotting}

Cells were harvested in cell lysis buffer $(50 \mathrm{mM}$ Tris, $\mathrm{pH} 7.5,150 \mathrm{mM} \mathrm{NaCl}, 1 \%$ Triton X-100, $1 \mathrm{mM}$ EDTA, $2.5 \mathrm{mM}$ sodium pyrophosphate, $1 \% \mathrm{Na}_{3} \mathrm{VO}_{4}$,
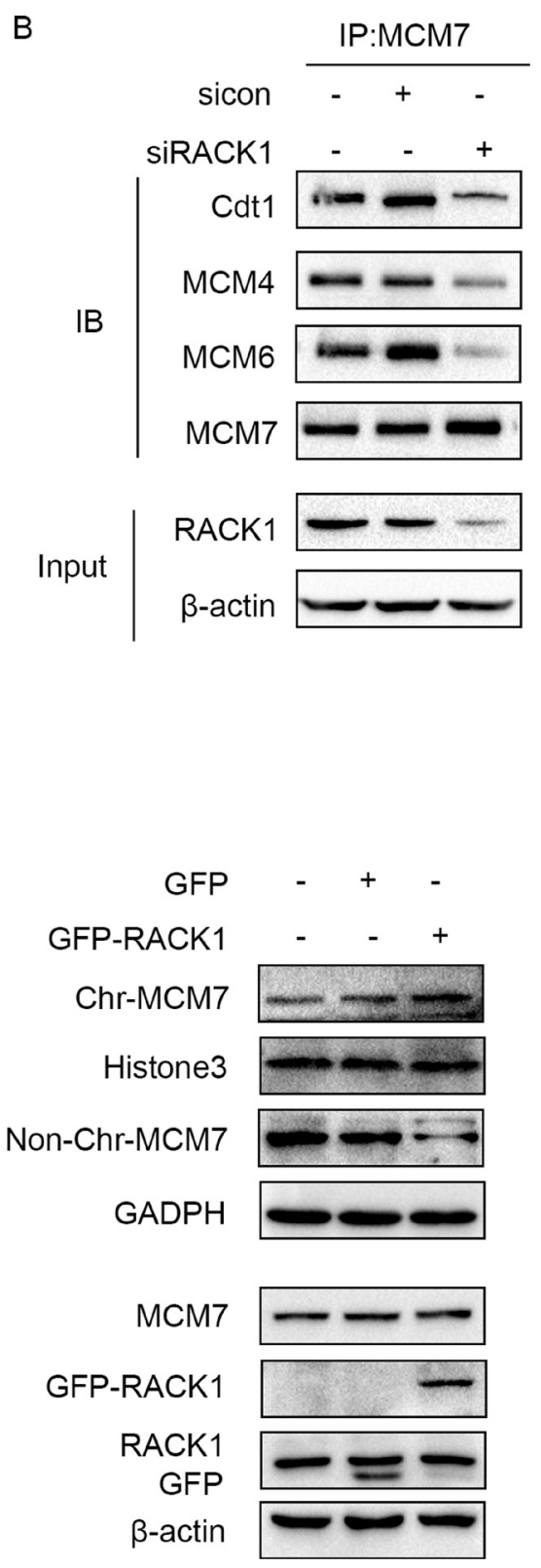

Figure 4: RACK1 promotes phosphorylation of MCM7. (A) A549 cells were transfected with siRACK1, siCon, GFP-RACK1, or GFP. MCM7 immunoprecipitates were probed for P-Ser, P-Thr, and MCM7 as indicated. (B) A549 cells were transfected with siRACK1 or siCon. MCM7 immunoprecipitates were probed for Cdt1, MCM4, MCM6, and MCM7. (C) A549 cells were treated with siRACK1, siCon, GFP-RACK1, or GFP as indicated. The chromatin (Chr) and non-chromatin (Non-Chr) fractions of these cells were purified and immunoblotted with anti-MCM7 antibodies. Antibodies against Histone 3 and GADPH were used as internal controls. 
$1 \mathrm{mM}$ PMSF, $0.5 \mu \mathrm{g} / \mathrm{mL}$ leupeptin, $10 \mu \mathrm{g} / \mathrm{mL}$ aprotinin, $1 \mathrm{mM}$ phosphatase inhibitors). Cell lysates were incubated on ice for $30 \mathrm{~min}$ and then centrifuged at $12000 \mathrm{rpm}$ for $20 \mathrm{~min}$. The resulting supernatants were collected and assayed in immunoblotting experiments. For immunoprecipitation experiments, the relevant antibodies were added ( $1 \mu \mathrm{g} / 1 \mathrm{mg}$ lysates) and incubated at $4{ }^{\circ} \mathrm{C}$ overnight. Fifty $\mu \mathrm{L}$ of protein $\mathrm{A} / \mathrm{G}$ beads were then added and incubated for an additional $4 \mathrm{~h}$ at $4^{\circ} \mathrm{C}$. The beads were collected, washed 5 times with lysis buffer, and

A
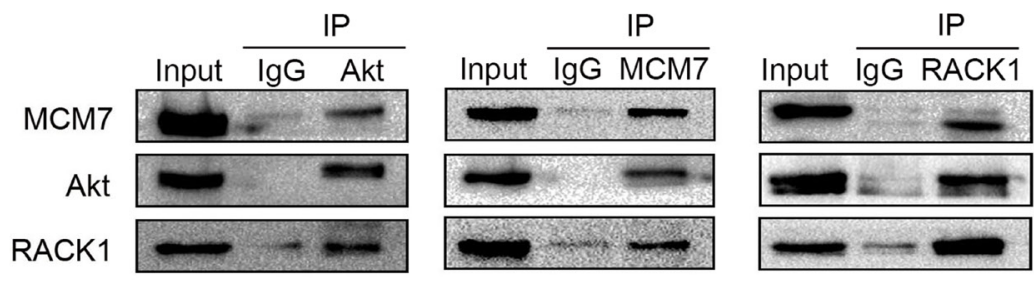

B

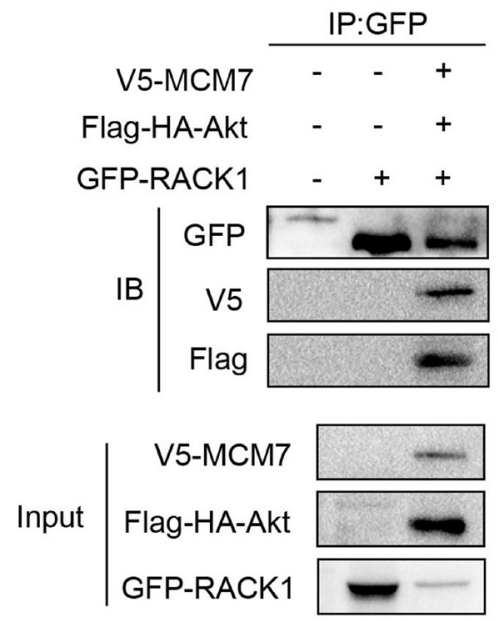

C

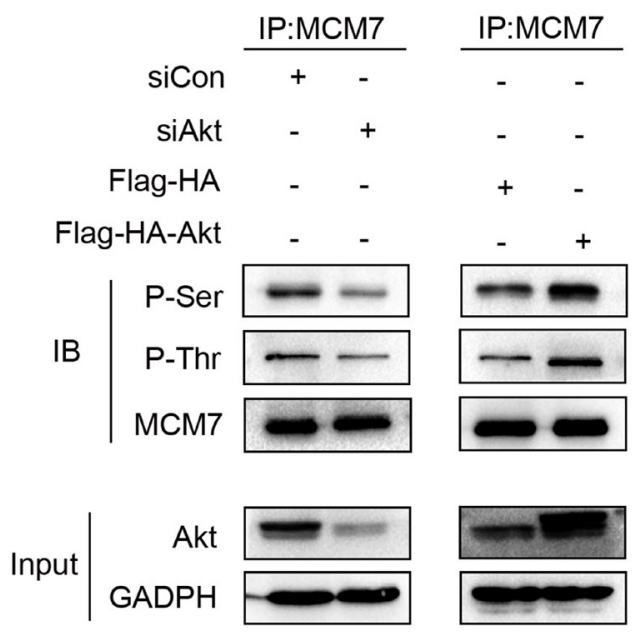

D

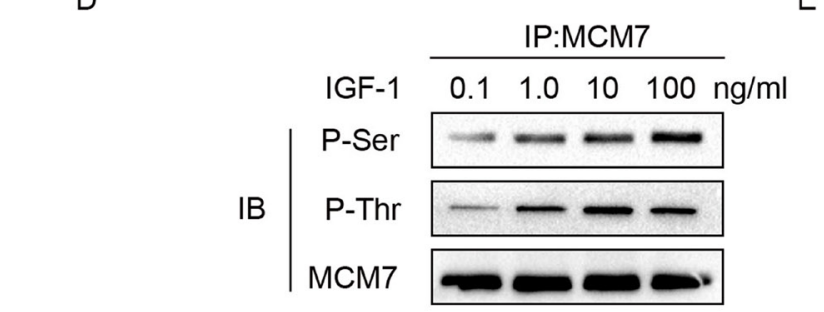

$E$
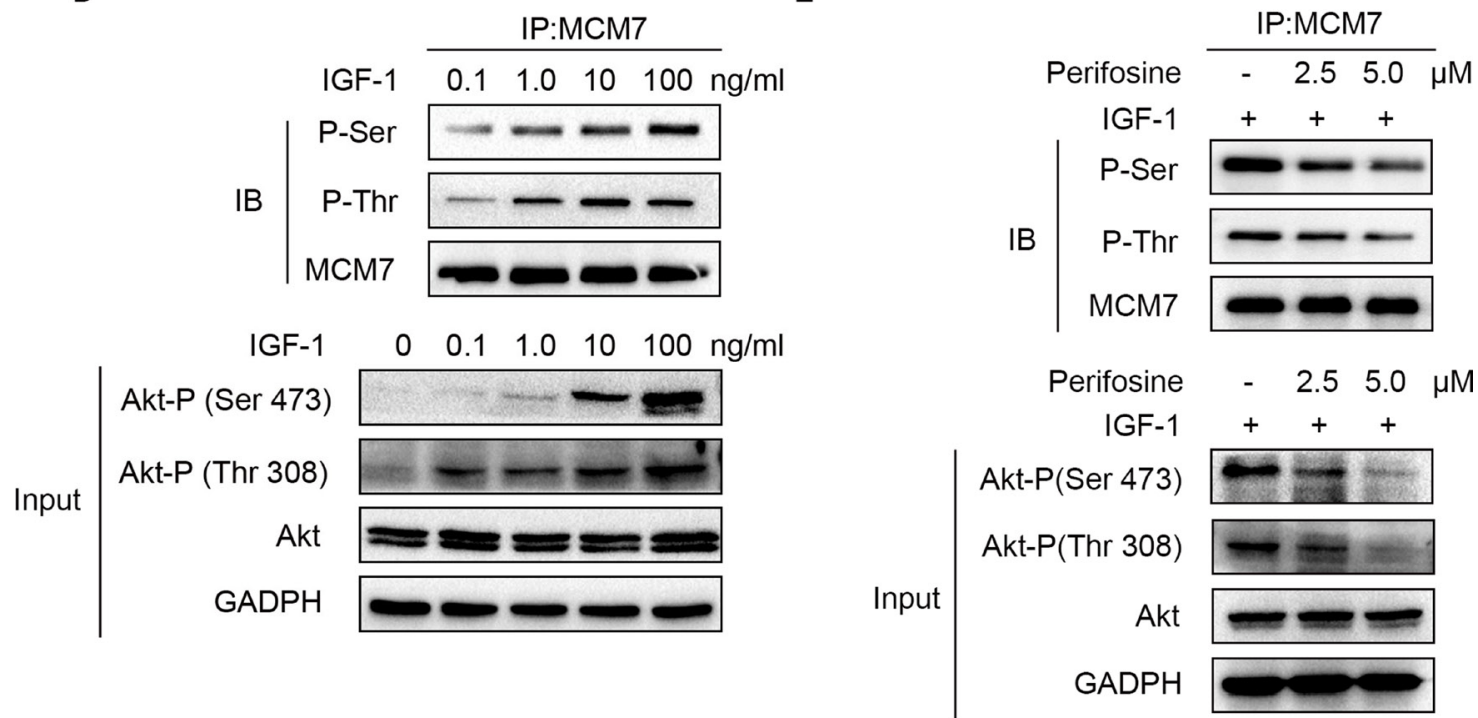

Figure 5: Akt regulates MCM7's phosphorylation. (A) A549 cell lysates were immunoprecipitated with Akt, MCM7, or RACK1 antibody and then immunoblotted with the indicated antibodies. (B) A549 cells were transfected with GFP-RACK1 together with V5-MCM7 and Flag-HA-Akt. Cell lysates were immunoprecipitated with GFP antibody and then immunoblotted with GFP or V5 or Flag antibody. (C) A549 cells were transfected with siRNA Akt (siAkt), siRNA control (siCon), pcDNA-Flag-HA-Akt1 (Flag-HA-Akt), or pcDNA-Flag-HAAkt1 (Flag-HA). MCM7 immunoprecipitates were probed for P-Ser, P-Thr, and MCM7. (D) A549 cells were serum-starved overnight and then treated with different doses of IGF-1 as indicated for 10 min. MCM7 immunoprecipitates were probed for P-Ser, P-Thr, and MCM7. (E) Serum-starved A549 cells were treated with 2.5 or $5.0 \mu \mathrm{M}$ perifosine as indicated for $1 \mathrm{~h}$ prior to the addition of $100 \mathrm{ng} / \mathrm{mL}$ IGF-1 for 10 min. MCM7 immunoprecipitates were probed for P-Ser, P-Thr, and MCM7. 
resuspended in $1 \times$ SDS sample buffer. The samples were then separated by SDS-PAGE and immunoblotted using the relevant antibodies.

\section{Chromatin association assay}

The chromatin association assay was performed as previously described [37]. Cells were lysed in $1 \mathrm{~mL}$ of Buffer A (15 mM NaC $\mathrm{H}_{3} \mathrm{O}_{2}, 110 \mathrm{mM} \mathrm{KC}_{2} \mathrm{H}_{3} \mathrm{O}_{2}, 2 \mathrm{mM}$ $\mathrm{MgC}_{2} \mathrm{H}_{3} \mathrm{O}_{2}, 0.5 \mathrm{mM}$ EGTA, and $20 \mathrm{mM}$ HEPES, $\mathrm{pH}$ 7.3). DTT and digitonin were then added to the cell suspension at final concentrations of $2 \mathrm{mmol} / \mathrm{L}$ and $50 \mathrm{mg} / \mathrm{mL}$, respectively, and suspensions were placed on ice for $10 \mathrm{~min}$. The suspension was then centrifuged at $1500 \mathrm{~g}$ for $10 \mathrm{~min}$ at $4^{\circ} \mathrm{C}$. Pelleted nuclei were resuspended in hypotonic buffer (Buffer B: 1 mM HEPES, pH 7.5, 0.5 mM EDTA supplemented with $0.5 \%$ NP40). The nuclear suspensions were then placed on ice for 15 minutes and laid on top of a $10-\mathrm{mL}$ sucrose cushion $(100 \mathrm{mM}$ sucrose and $0.5 \mathrm{mM}$ Tris- $\mathrm{HCl}, \mathrm{pH} 8.5)$ and centrifuged at $3500 \mathrm{~g}$ for 10 minutes at $4{ }^{\circ} \mathrm{C}$. The chromatin pellets were suspended in $0.25 \mathrm{mM}$ EDTA (pH 8.0) and sonicated for 10 seconds two times per
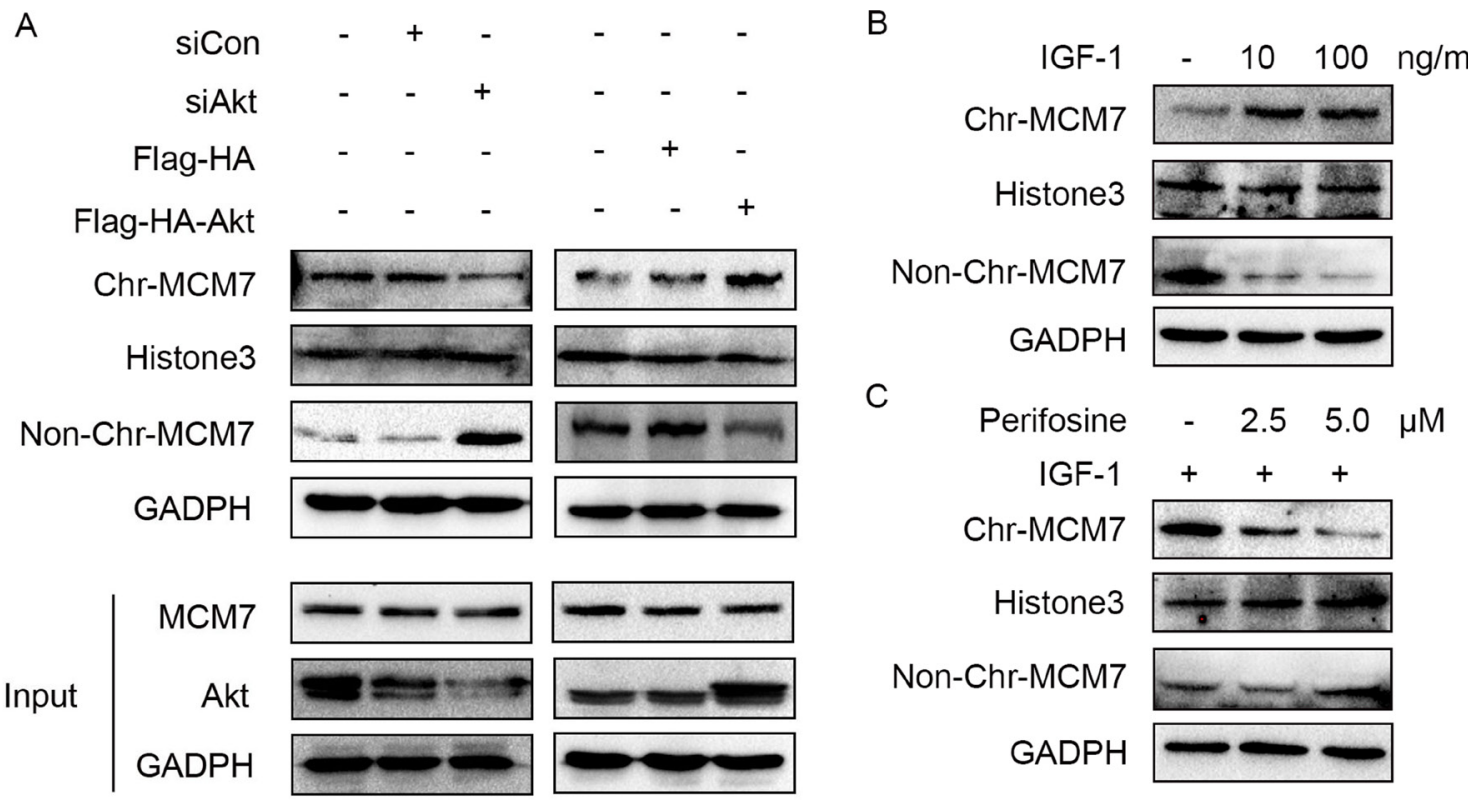

Figure 6: Akt regulates MCM7's loading on chromatin. (A) A549 cells were transfected with siAkt, siCon, Flag-HA-Akt, or not treated. The chromatin (Chr) and non-chromatin (Non-Chr) fractions of these cells were purified and immunoblotted with anti-MCM7 antibodies. (B) A549 cells were serum-starved overnight and then treated with 10 or 100ng/mL IGF-1 for 10min as indicated. The chromatin (Chr) and non-chromatin (Non-Chr) fractions of these cells were purified and immunoblotted with anti-MCM7 antibodies. (C) Serumstarved A549 cells were treated with 2.5 or $5.0 \mu \mathrm{M}$ perifosine as indicated for $1 \mathrm{~h}$ prior to the addition of $100 \mathrm{ng} / \mathrm{mL}$ IGF-1 for $10 \mathrm{~min}$. The chromatin (Chr) and non-chromatin (Non-Chr) fractions of these cells were purified and immunoblotted with anti-MCM7 antibodies.

A

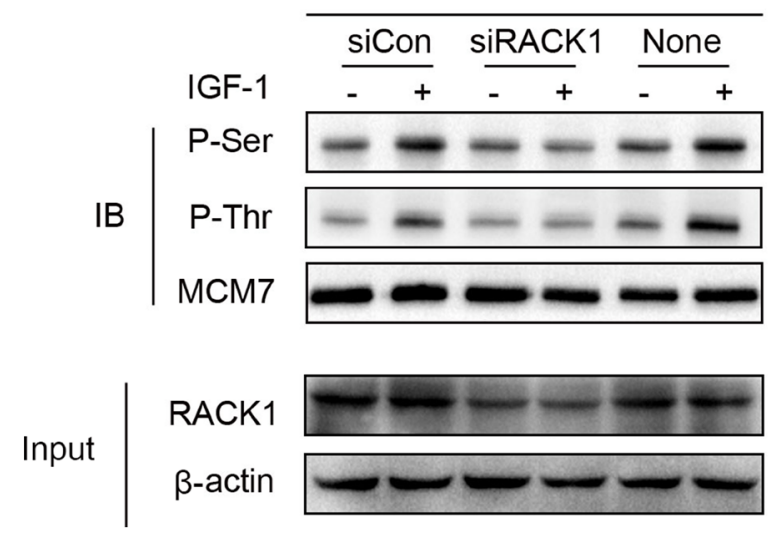

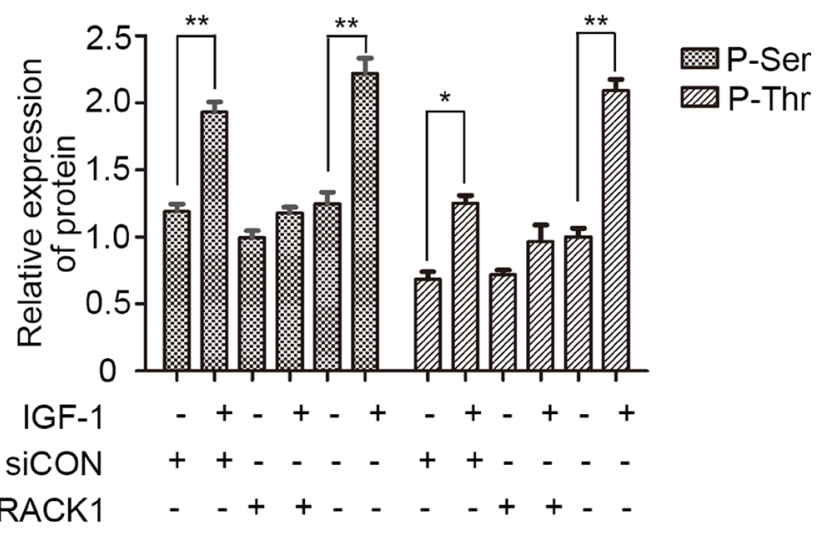

Figure 7: RACK1 is required for the interaction between Akt and MCM7. (A) A549 cells were transfected with siRACK1 or siCon, serum-starved, and then treated with $100 \mathrm{ng} / \mathrm{mL}$ IGF-1 for $10 \mathrm{~min}$. MCM7 immunoprecipitates were probed for P-Ser, P-Thr, and MCM7. 
sample to produce a chromatin-rich supernatant fraction. Proteins in these fractions were quantitated and analyzed using SDS-PAGE.

\section{Colony formation assay}

The A549 and H460 cells were plated in 40-mm dishes $24 \mathrm{~h}$ after transfection (1000 per dish) and incubated for 12 days. Medium containing 10\% fetal bovine serum was replaced every 4 days. On day 12 , the plates were washed with PBS, stained with hematoxylin, and the number of colonies with more than 50 cells was counted.

\section{3-(4,5-Dimethylthiazol-2-yl)-2,5- diphenyltetrazolium bromide (MTT) assay}

Cells were plated in 96-well plates at a concentration of 3000-5000 cells per well $24 \mathrm{~h}$ after transfection. To measure cell growth, $20 \mu \mathrm{L}$ of $5 \mathrm{mg} / \mathrm{mL}$ MTT was added to the media and samples were incubated for $4 \mathrm{~h}$ at $37^{\circ} \mathrm{C}$. The media were then removed, $200 \mu \mathrm{L}$ of DMSO was added to dissolve the generated deposits, and the absorbance at $490 \mathrm{~nm}$ was measured using an automatic microplate reader. The measurement process was performed every $24 \mathrm{~h}$ for 5 days to generate a cell growth curve.

\section{Immunofluorescence}

Twenty-four hours after they were plated on covered slides, cells were washed 3 times with ice-cold PBS and fixed in $4 \%$ paraformaldehyde for $20 \mathrm{~min}$ at room temperature. After two PBS washes, the cells were blocked with $3 \%$ BSA with $0.2 \%$ Triton X-100. Cells were then stained with primary antibodies diluted in $3 \%$ BSA overnight at $4^{\circ} \mathrm{C}$. After 3 washes in PBS, cells were incubated for $2 \mathrm{~h}$ with the secondary donkey anti-mouse (fluorescein isothiocyanate conjugated, 1:300) or goat anti-rabbit (tetramethylrhodamine-isothiocyanatee conjugated, 1:300) antibodies, as appropriate. Nuclei were counterstained with propidium iodide (PI, $50 \mu \mathrm{g} / \mathrm{mL}$, Sigma).

\section{Flow cytometry}

For DNA content analysis, cells were fixed in 70\% ethanol overnight at $4^{\circ} \mathrm{C}$ and then washed with $\mathrm{PBS}$ containing 1\% BSA. Cells were incubated in $50 \mu \mathrm{g} / \mathrm{mL}$ propidium iodide and $100 \mu \mathrm{g} / \mathrm{mL}$ RNase A for $30 \mathrm{~min}$, and 10000 cells per sample were analyzed using a FACSCalibur cytometer (BD Biosciences).

\section{Yeast two-hybrid screening}

The fusion protein pGBKT7-MCM7 contained 719 amino acids from MCM7 and 219 amino acids from bait domain [37]. The construct was transformed into One
ShotTM competent cells (Invitrogen, Carlsbad, CA). pAD-RACK1 was constructed in pACT2 in $0.5 \mathrm{~mL}$ of polyethylene glycol/LiAc and incubated at $30^{\circ} \mathrm{C}$ for 30 minutes. After this initial incubation with plasmid DNA, the cell solution was combined with $20 \mathrm{~mL}$ of DMSO and incubated for 15 minutes at $42^{\circ} \mathrm{C}$. The cells were pelleted, resuspended in $1 \mathrm{~mL}$ YPD medium, and shaken at $30^{\circ} \mathrm{C}$ for 40 minutes. The transformed cells were then pelleted, resuspended in $0.5 \mathrm{~mL} 0.9 \%$ $\mathrm{NaCl}$, and plated onto the appropriate SD agar plate. The transformants were first plated on low stringency SD-Leu/-Trp and medium stringency SD-Leu/-Trp/His plates. The colonies that grew on those plates were then subjected to the $\beta$-galactosidase assay as previously described for 24 and then allowed to grow further on the high stringency SD-Ade/-His/-Leu/-Trp plate.

\section{Patients and specimens}

This research was approved by the Human Research Ethics Committee of China Medical University, which is accredited by the National Council on Ethics in Human Research. All patients signed informed consents and were closely monitored during follow-up observations. None of the patients received chemotherapy or radiotherapy prior to operations.

\section{Primary tumor specimens}

Primary NSCLC and matched normal lung tissue specimens were obtained from 28 patients who underwent surgical resection at the First Affiliated Hospital of China Medical University between 2010 and 2011. Samples were cut from the resected lungs immediately after removal, frozen in liquid nitrogen, and then stored at $-80^{\circ} \mathrm{C}$.

\section{Paraffin sections}

The following tissue chips were purchased from Shanghai Core Super Biological Technology Co., LTD: lung cancer 120 point OD-CT-DgLug01-007 (20 adenocarcinoma cases, 10 squamous cell carcinoma cases, 10 adenosquamous carcinoma cases, 10 large cell lung cancer cases, 10 small cell lung cancer cases), lung adenocarcinoma 150 point OD-CT-RsLug01-008 (75 adenocarcinoma cases), and lung squamous cell carcinoma 150 point OD-CT-RsLug01-009 (75 squamous cell carcinoma cases). One hundred fifty NSCLC cases contained detailed information and prognostic information (78 adenocarcinoma cases, 72 squamous cell carcinoma cases).

\section{Immunohistochemical analysis}

Briefly, tissue samples were deparaffinized in xylene and endogenous peroxidase activity was blocked with $4 \% \mathrm{H}_{2} \mathrm{O}_{2}$. The sections were incubated with RACK1specific mouse polyclonal antibody (1:100 dilution) or MCM7-specific rabbit polyclonal antibody (1:50 dilution) 
overnight at $4^{\circ} \mathrm{C}$, incubated with biotin-labeled secondary antibodies (Ultrasensitive; Fuzhou MaiXin Biotechnology Development Co., Ltd., Fujian, China) at $37^{\circ} \mathrm{C}$ for $30 \mathrm{~min}$, and then incubated with diaminobenzidine for coloration.

\section{RNA extraction and RT-PCR}

Total RNA was isolated from NSCLC patient tissues using TRIzol reagent (Invitrogen, USA) according to the manufacturer's instructions. The cDNA templates were as follows: RACK1 (357 bp) fragment with primers 5'-TGAGTGTGGCCTTCTCCTCT-3' (forward) and 5'-AAAGGTGTTTGCCTTCGTTG-3' (reverse); MCM7 (382 bp) fragment with primers 5'-ACCGAGACAATGACCTACGG-3' (forward) and 5'-CTAGCTGTCTGCCCCTTGTC-3' (reverse); and internal control gene $\beta$-actin (345 bp) with primers 5'-CTCCATCCTGGCCTCGCTGT-3' (forward) and 5'-GCTGTCACCTTCACCGTTCC-3' (reverse). Thermal cycling reactions were performed using standard conditions with annealing temperatures of $58.0^{\circ} \mathrm{C}$ (for RACK 1 ), $60.0^{\circ} \mathrm{C}$ (for $\mathrm{MCM} 7$ ) and $55.5^{\circ} \mathrm{C}$ (for $\beta$-actin), respectively, for 40 cycles. The products were electrophoresed on $1.2 \%$ agarose gels and then semi-quantified using the Gelpro Analyzer image analysis software package (Media Cybernetics, USA).

\section{Statistics}

Immunohistochemistry results were analyzed using the chi-square test and Spearman rank correlation. KaplanMeier survival analyses were carried out and compared using the log-rank test. Differences between groups were compared using two-tailed Student's $t$-test; $p$ values $<0.05$ $(*)$ or $<0.01(* *)$ were considered statistically significant.

\section{Abbreviations}

MCM7: Miniature chromosome maintenance 7; RACK1: Receptor for activated C kinase 1; ORC: Origin recognition complex; NSCLC: Non-small-cell Lung Cancer.

\section{Authors' contributions}

Yuchen Han provided constructive comments and suggestions on the manuscript. Liangru Fei, Yinan Ma, Mei-Yu Zhang, Xiaofang Liu, Yuan Luo, CongCong Wang, Wenzhu Zhang and Haiyan Zhang provided technical support. All authors read and approved the final manuscript.

\section{ACKNOWLEDGMENTS}

We thank Dr. Jianhua Luo (University of Pittsburgh School of Medicine, Pittsburgh, Pennsylvania) for generously providing the pGBKT7-MCM7 and pGADT7RACK1 plasmids.

\section{CONFLICTS OF INTEREST}

The authors do not have any conflicts of interest to report.

\section{FUNDING}

This work was supported by the National Natural Science Foundation of China (grant No. 81272605 and No. 30971114).

\section{REFERENCES}

1. Gonzalez MA, Tachibana KE, Laskey RA, Coleman N. Control of DNA replication and its potential clinical exploitation. Nat Rev Cancer. 2005; 5:135-41.

2. Maiorano D, Lutzmann M, Mechali M. MCM proteins and DNA replication. Curr Opin Cell Biol. 2006; 18:130-6.

3. Yan H, Merchant AM, Tye BK. Cell cycle-regulated nuclear localization of MCM2 and MCM3, which are required for the initiation of DNA synthesis at chromosomal replication origins in yeast. Genes Dev. 1993; 7:2149-60.

4. Lee JK, Hurwitz J. Processive DNA helicase activity of the minichromosome maintenance proteins 4, 6, and 7 complex requires forked DNA structures. Proc Natl Acad Sci USA. 2001; 98:54-9.

5. Labib K, Tercero JA, Diffley JF. Uninterrupted MCM2-7 function required for DNA replication fork progression. Science. 2000; 288:1643-7.

6. Ishimi Y. A DNA helicase activity is associated with an MCM4, -6, and -7 protein complex. J Biol Chem. 1997; 272:24508-13.

7. Lei M, Tye BK. Initiating DNA synthesis: from recruiting to activating the MCM complex. J Cell Sci. 2001; 114:1447-54.

8. Kearsey SE, Labib K. MCM proteins: evolution, properties, and role in DNA replication. Biochim Biophys Acta. 1998; 1398:113-36.

9. Dalton S, Whitbread L. Cell cycle-regulated nuclear import and export of $\mathrm{Cdc} 47$, a protein essential for initiation of DNA replication in budding yeast. Proc Natl Acad Sci USA. 1995; 92:2514-8.

10. Coxon A, Maundrell K, Kearsey SE. Fission yeast cdc21+ belongs to a family of proteins involved in an early step of chromosome replication. Nucleic Acids Res. 1992; 20:5571-7.

11. Chong JP, Thommes P, Blow JJ. The role of MCM/ $\mathrm{P} 1$ proteins in the licensing of DNA replication. Trends Biochem Sci. 1996; 21:102-6.

12. Kearsey SE, Maiorano D, Holmes EC, Todorov IT. The role of MCM proteins in the cell cycle control of genome duplication. Bioessays. 1996; 18:183-90. 
13. Ren B, Yu G, Tseng GC, Cieply K, Gavel T, Nelson J, Michalopoulos G, Yu YP, Luo JH. MCM7 amplification and overexpression are associated with prostate cancer progression. Oncogene. 2006; 25:1090-8.

14. Ota T, Clayton AC, Minot DM, Shridhar V, Hartmann LC, Gilks CB, Chien JR. Minichromosome maintenance protein 7 as a potential prognostic factor for progression-free survival in high-grade serous carcinomas of the ovary. Mod Pathol. 2011; 24:277-87.

15. Li SS, Xue WC, Khoo US, Ngan HY, Chan KY, Tam IY, Chiu PM, Ip PP, Tam KF, Cheung AN. Replicative MCM7 protein as a proliferation marker in endometrial carcinoma: a tissue microarray and clinicopathological analysis. Histopathology. 2005; 46:307-13.

16. Feng CJ, Li HJ, Li JN, Lu YJ, Liao GQ. Expression of $\mathrm{Mcm} 7$ and Cdc6 in oral squamous cell carcinoma and precancerous lesions. Anticancer Res. 2008; 28:3763-9.

17. Kan T, Sato F, Ito T, Matsumura N, David S, Cheng Y, Agarwal R, Paun BC, Jin Z, Olaru AV, Selaru FM, Hamilton JP, Yang J, et al. The miR-106b-25 polycistron, activated by genomic amplification, functions as an oncogene by suppressing p21 and Bim. Gastroenterology. 2009; 136:1689-700.

18. Nishihara K, Shomori K, Fujioka S, Tokuyasu N, Inaba A, Osaki M, Ogawa T, Ito H. Minichromosome maintenance protein 7 in colorectal cancer: implication of prognostic significance. Int J Oncol. 2008; 33:245-51.

19. Facoetti A, Ranza E, Benericetti E, Ceroni M, Tedeschi F, Nano R. Minichromosome maintenance protein 7: a reliable tool for glioblastoma proliferation index. Anticancer Res. 2006; 26:1071-5.

20. Cortez D, Glick G, Elledge SJ. Minichromosome maintenance proteins are direct targets of the ATM and ATR checkpoint kinases. Proc Natl Acad Sci USA. 2004; 101:10078-83.

21. Tsao CC, Geisen C, Abraham RT. Interaction between human MCM7 and Rad17 proteins is required for replication checkpoint signaling. EMBO J. 2004; 23:4660-9.

22. Shohet JM, Hicks MJ, Plon SE, Burlingame SM, Stuart S, Chen SY, Brenner MK, Nuchtern JG. Minichromosome maintenance protein MCM7 is a direct target of the MYCN transcription factor in neuroblastoma. Cancer Res. 2002; 62:1123-8.

23. Liu YZ, Jiang YY, Hao JJ, Lu SS, Zhang TT, Shang L, Cao J, Song X, Wang BS, Cai Y, Zhan QM, Wang MR. Prognostic significance of MCM7 expression in the bronchial brushings of patients with non-small cell lung cancer (NSCLC). Lung Cancer. 2012; 77:176-82.

24. Toyokawa G, Masuda K, Daigo Y, Cho HS, Yoshimatsu M, Takawa M, Hayami S, Maejima K, Chino M, Field HI, Neal DE, Tsuchiya E, Ponder BA, et al. Minichromosome Maintenance Protein 7 is a potential therapeutic target in human cancer and a novel prognostic marker of non-small cell lung cancer. Mol Cancer. 2011; 10:65.
25. Padmanabhan V, Callas P, Philips G, Trainer TD, Beatty BG. DNA replication regulation protein $\mathrm{Mcm} 7$ as a marker of proliferation in prostate cancer. J Clin Pathol. 2004; 57:1057-62.

26. Ron D, Chen CH, Caldwell J, Jamieson L, Orr E, MochlyRosen D. Cloning of an intracellular receptor for protein kinase C: a homolog of the beta subunit of $\mathrm{G}$ proteins. Proc Natl Acad Sci USA. 1994; 91:839-43.

27. Chang BY, Conroy KB, Machleder EM, Cartwright CA. RACK1, a receptor for activated $\mathrm{C}$ kinase and a homolog of the beta subunit of $\mathrm{G}$ proteins, inhibits activity of src tyrosine kinases and growth of NIH $3 \mathrm{~T} 3$ cells. Mol Cell Biol. 1998; 18:3245-56.

28. Chang BY, Chiang M, Cartwright CA. The interaction of Src and RACK1 is enhanced by activation of protein kinase $\mathrm{C}$ and tyrosine phosphorylation of RACK1. J Biol Chem. 2001; 276:20346-56.

29. Chang BY, Harte RA, Cartwright CA. RACK1: a novel substrate for the Src protein-tyrosine kinase. Oncogene. 2002; 21:7619-29.

30. Liliental J, Chang DD. Rack1, a receptor for activated protein kinase $\mathrm{C}$, interacts with integrin beta subunit. J Biol Chem. 1998; 273:2379-83.

31. Li G, Ji XD, Gao H, Zhao JS, Xu JF, Sun ZJ, Deng YZ, Shi S, Feng YX, Zhu YQ, Wang T, Li JJ, Xie D. EphB3 suppresses non-small-cell lung cancer metastasis via a PP2A/RACK1/Akt signalling complex. Nat Commun. 2012; 3:667.

32. Huang CC, Liu CH, Chuang NN. An enhanced association of RACK1 with Abl in cells transfected with oncogenic ras. Int J Biochem Cell Biol. 2008; 40:423-31.

33. Li JJ, Xie D. RACK1, a versatile hub in cancer. Oncogene. 2015; 34:1890-8.

34. Zhou H, Li XM, Meinkoth J, Pittman RN. Akt regulates cell survival and apoptosis at a postmitochondrial level. J Cell Biol. 2000; 151:483-94.

35. Vincent EE, Elder DJ, Thomas EC, Phillips L, Morgan C, Pawade J, Sohail M, May MT, Hetzel MR, Tavare JM. Akt phosphorylation on Thr308 but not on Ser473 correlates with Akt protein kinase activity in human non-small cell lung cancer. Br J Cancer. 2011; 104:1755-61.

36. Nilsson J, Sengupta J, Frank J, Nissen P. Regulation of eukaryotic translation by the RACK 1 protein: a platform for signalling molecules on the ribosome. EMBO Rep. 2004; 5:1137-41.

37. Han YC, Yu YP, Nelson J, Wu C, Wang $\mathrm{H}$, Michalopoulos GK, Luo JH. Interaction of integrin-linked kinase and miniature chromosome maintenance 7-mediating integrin \{alpha\} 7 induced cell growth suppression. Cancer Res. 2010; 70:4375-84.

38. Wei Q, Li J, Liu T, Tong X, Ye X. Phosphorylation of minichromosome maintenance protein 7 (MCM7) by cyclin/cyclin-dependent kinase affects its function in cell cycle regulation. J Biol Chem. 2013; 288:19715-25. 
39. Huang TH, Huo L, Wang YN, Xia W, Wei Y, Chang SS, Chang WC, Fang YF, Chen CT, Lang JY, Tu C, Wang Y, Hsu MC, et al. Epidermal growth factor receptor potentiates MCM7-mediated DNA replication through tyrosine phosphorylation of Lyn kinase in human cancers. Cancer Cell. 2013; 23:796-810.

40. Mukherjee P, Winter SL, Alexandrow MG. Cell cycle arrest by transforming growth factor beta 1 near $\mathrm{G} 1 / \mathrm{S}$ is mediated by acute abrogation of prereplication complex activation involving an Rb-MCM interaction. Mol Cell Biol. 2010; 30:845-56.

41. Zhang XY, Tang LZ, Ren BG, Yu YP, Nelson J, Michalopoulos G, Luo JH. Interaction of MCM7 and RACK1 for activation of MCM7 and cell growth. Am J Pathol. 2013; 182:796-805.

42. Khanna RS, Le HT, Wang J, Fung TC, Pallen CJ. The interaction of protein-tyrosine phosphatase alpha (PTPalpha) and RACK1 protein enables insulin-like growth factor 1 (IGF-1)-stimulated Abl-dependent and -independent tyrosine phosphorylation of PTPalpha. J Biol Chem. 2015; 290:9886-95.

43. Nagashio R, Sato Y, Matsumoto T, Kageyama T, Satoh Y, Shinichiro R, Masuda N, Goshima N, Jiang SX, Okayasu I. Expression of RACK1 is a novel biomarker in pulmonary adenocarcinomas. Lung Cancer. 2010; 69:54-9.

44. Shi S, Deng YZ, Zhao JS, Ji XD, Shi J, Feng YX, Li G, Li JJ, Zhu D, Koeffler HP, Zhao Y, Xie D. RACK1 promotes non-small-cell lung cancer tumorigenicity through activating sonic hedgehog signaling pathway. J Biol Chem. 2012; 287:7845-58.

45. Li X, Xiao Y, Fan S, Xiao M, Wang X, Chen X, Li C, Zong G, Zhou G, Wan C. RACK1 overexpression associates with pancreatic ductal adenocarcinoma growth and poor prognosis. Exp Mol Pathol. 2016; 101:176-86.

46. Lv QL, Huang YT, Wang GH, Liu YL, Huang J, Qu Q, Sun B, Hu L, Cheng L, Chen SH, Zhou HH. Overexpression of RACK1 Promotes Metastasis by Enhancing EpithelialMesenchymal Transition and Predicts Poor Prognosis in Human Glioma. Int J Environ Res Public Health. 2016; 13.

47. Zhang X, Liu N, Ma D, Liu L, Jiang L, Zhou Y, Zeng X, Li J, Chen Q. Receptor for activated C kinase 1 (RACK1) promotes the progression of OSCC via the AKT/mTOR pathway. Int J Oncol. 2016; 49:539-48.

48. Mamidipudi V, Dhillon NK, Parman T, Miller LD, Lee KC, Cartwright CA. RACK1 inhibits colonic cell growth by regulating Src activity at cell cycle checkpoints. Oncogene. 2007; 26:2914-24.
49. Mamidipudi V, Zhang J, Lee KC, Cartwright CA. RACK1 regulates G1/S progression by suppressing Src kinase activity. Mol Cell Biol. 2004; 24:6788-98.

50. Yaka R, He DY, Phamluong K, Ron D. Pituitary adenylate cyclase-activating polypeptide (PACAP(1-38)) enhances $\mathrm{N}$-methyl-D-aspartate receptor function and brain-derived neurotrophic factor expression via RACK1. J Biol Chem. $2003 ; 278: 9630-8$.

51. He DY, Neasta J, Ron D. Epigenetic regulation of BDNF expression via the scaffolding protein RACK1. J Biol Chem. 2010; 285:19043-50.

52. He DY, Vagts AJ, Yaka R, Ron D. Ethanol induces gene expression via nuclear compartmentalization of receptor for activated C kinase 1. Mol Pharmacol. 2002; 62:272-80.

53. Ron D, Vagts AJ, Dohrman DP, Yaka R, Jiang Z, Yao L, Crabbe J, Grisel JE, Diamond I. Uncoupling of betaIIPKC from its targeting protein RACK1 in response to ethanol in cultured cells and mouse brain. FASEB J. 2000; 14:2303-14.

54. Kiely PA, Sant A, O'Connor R. RACK1 is an insulin-like growth factor 1 (IGF-1) receptor-interacting protein that can regulate IGF-1-mediated Akt activation and protection from cell death. J Biol Chem. 2002; 277:22581-89.

55. He X, Wang J, Messing EM, Wu G. Regulation of receptor for activated $\mathrm{C}$ kinase 1 protein by the von Hippel-Lindau tumor suppressor in IGF-I-induced renal carcinoma cell invasiveness. Oncogene. 2011; 30:535-47.

56. Mamidipudi V, Cartwright CA. A novel pro-apoptotic function of RACK1: suppression of Src activity in the intrinsic and Akt pathways. Oncogene. 2009; 28:4421-33.

57. Cox EA, Bennin D, Doan AT, O'Toole T, Huttenlocher A. RACK1 regulates integrin-mediated adhesion, protrusion, and chemotactic cell migration via its Src-binding site. Mol Biol Cell. 2003; 14:658-69.

58. Scott KL, Nogueira C, Heffernan TP, van Doorn R, Dhakal S, Hanna JA, Min C, Jaskelioff M, Xiao Y, Wu CJ, Cameron LA, Perry SR, Zeid R, et al. Proinvasion metastasis drivers in early-stage melanoma are oncogenes. Cancer Cell. 2011; 20:92-103.

59. Hsieh AC, Bo R, Manola J, Vazquez F, Bare O, Khvorova A, Scaringe S, Sellers WR. A library of siRNA duplexes targeting the phosphoinositide 3-kinase pathway: determinants of gene silencing for use in cell-based screens. Nucleic Acids Res. 2004; 32:893-901. 